\title{
FAMILIAL PATTERNS IN ISCHAEMIC HEART DISEASE
}

\author{
BY \\ GEOFFREY ROSE* \\ From the Department of Epidemiology, School of Hygiene and Public Health, Johns Hopkins University, Baltimore, \\ Maryland, U.S.A.
}

Certain aspects of the problem of ischaemic heart disease have been studied very intensively, but of others we still know relatively little. Thus many of the personal characteristics of affected individuals are now well known; but the characteristics of their families have received little attention.

It is widely held that the disease shows familial aggregation, largely because some families contain a remarkable number of cases. But the disease is very common, and such evidence could be misleading. The few reported controlled studies have involved a serious risk of bias in selection of controls or in reporting procedures (Gertler and White, 1954; Thomas and Cohen, 1955; Russek and Zohman, 1958; Shanoff, Little, Murphy, and Rykert, 1961) or in diagnostic accuracy (Ciocco, 1941). On the broader question of the general health characteristics of affected families there is even less information.

In the present study special attention was given to careful matching of controls, and to eliminating or measuring bias in reporting procedures. The aim was to investigate the existence and extent of familial aggregation of the disease, and to study also a wide range of health characteristics of the index families. A new method is described for testing for familial aggregation which dispenses with the need for a control group.

\section{MeTHODS}

The index propositi were 75 consecutive white patients (65 men and 10 women) who had been admitted to the Johns Hopkins Hospital, Baltimore, with cardiac infarction proven by electrocardiography or raised serum transaminase, and who were alive and resident in or near Baltimore at the time of the study. An upper age limit was set at 70 years at the time of interview. There were fourteen exclusions (10 male and 4 female) because of death before interview.

* Present address: London School of Hygiene and Tropical Medicine, Keppel Street, London, W.C.1.
For each index case a control was selected, this being the next available patient of the same sex and age ( \pm 5 years). Index cases who were manual workers were matched by manual worker controls, and clerical index cases by clerical controls. The control cases were drawn from the medical and general surgical wards. Patients were not accepted as controls if they had been admitted to hospital because of a disease known to carry an abnormal risk of arterial disease or hypertension, since this bias might make them unrepresentative of the general population. They were also excluded if they were known incidentally to have evidence of ischaemic heart disease. There were eighteen cases of cancer, 24 of alimentary disease, five of lung disease, and 28 of a variety of other diseases.

Each participant was interviewed by the use of a fully standardized questionnaire. There were two interviewers; to avoid bias, each interviewed both index cases and controls. Great care was taken to avoid any departures from the printed questions. The subjects were asked first about their own health, including details of their present illness and of certain specified past illnesses. They were then asked about their parents, uncles and aunts, siblings, and children, particularly with regard to heart disease, family size, survivorship, and cause of death.

The analysis of causes of death is based on the statements made at interview. In order to assess the risk of biased reporting, copies of death certificates were obtained for a sample of the deaths in each group, and a comparison was made between the cause of death given at interview and as stated on the death certificate.

\section{Results}

\section{Characteristics of the Propositi}

There were no remarkable differences between the index and control groups as to marital status or age (mean 55.9 years for index cases, 54.6 years for controls). As to place of birth, among the American- 
born index males there was an excess of men born in Maryland (i.e. their present state of residence: $\left.\chi^{2}=5.06 ; P=0.05 / 0.02\right)$. The choice of controls involved approximate occupational matching, so that major socio-economic differences were precluded. There were nevertheless more private patients in the index group ( 31 persons) than among the controls ( 23 persons).

Participants were questioned about their past medical histories. For childhood illnesses there was close agreement between the two groups. This suggests comparability with regard not only to childhood health, but also to reliability of memory and recall. For hospital illnesses, however, the index group had a worse experience; the difference was consistent for both medical and surgical admissions, and for both men and women. The excess was fairly evenly distributed throughout life, and covered a wide range of diagnoses. The proportion of smokers was the same in the index and control groups, but more index cases were heavy smokers.

On physical examination the index cases showed rather more hypertension and also more frequent arcus senilis (present in seven index cases but in only one control). In Table I the serum cholesterol levels are compared with control values as given by Manley and McKusick (1960) for patients of the Johns Hopkins Hospital (excluding those with diabetes,
TABLE I

SERUM CHOLESTEROL LEVELS IN INDEX PROPOSITI, COMPARED WITH THOSE IN A “CONTROL" HOSPITAL

\begin{tabular}{|c|c|c|c|c|c|}
\hline \multirow[b]{2}{*}{ Sex } & \multirow[b]{2}{*}{$\begin{array}{c}\text { Age } \\
\text { (yrs) }\end{array}$} & \multicolumn{2}{|c|}{ Index Propositi } & \multicolumn{2}{|c|}{ "Controls" } \\
\hline & & $\begin{array}{l}\text { No. of } \\
\text { Cases }\end{array}$ & $\begin{array}{l}\text { Mean Serum } \\
\text { Cholesterol } \\
\text { (mg./100 ml.) }\end{array}$ & $\begin{array}{l}\text { No. of } \\
\text { Cases }\end{array}$ & $\begin{array}{c}\text { Mean Serum } \\
\text { Cholesterol } \\
\text { (mg./100 ml.) }\end{array}$ \\
\hline Male.. & $\begin{array}{c}40-59 \\
60+\end{array}$ & $\begin{array}{l}39^{*} \\
22^{*}\end{array}$ & $\begin{array}{l}295 \\
262 \\
\end{array}$ & $\begin{array}{l}416 \\
140\end{array}$ & $\begin{array}{l}268 \\
259 \\
\end{array}$ \\
\hline Female .. & $\begin{array}{c}40-59 \\
60+ \\
\end{array}$ & $\begin{array}{l}4 \\
6 \\
\end{array}$ & $\begin{array}{l}364 \\
350 \\
\end{array}$ & $\begin{array}{l}363 \\
121 \\
\end{array}$ & $\begin{array}{l}280 \\
285 \\
\end{array}$ \\
\hline ota & & 71 & 293 & 1,040 & 273 \\
\hline
\end{tabular}

* Two missing specimens in each group.

diseases of the thyroid, liver, or kidney, or "atheromatous" disease). The younger coronary males show elevated levels, but in the $60+$ age group there is virtually no difference. The elevation is greater among coronary women, and although it diminishes in the older age group it does not disappear.

Family Size, Survivorship, and Health (Table II)

(a) Children of Propositi.-Family size and mortality were essentially the same in the index and control families. The reported incidence of various infections and other illnesses was also similar, which again suggests comparability between the groups in

TABLE II

MORTALITY OF PARENTS, SIBLINGS, AND CHILDREN

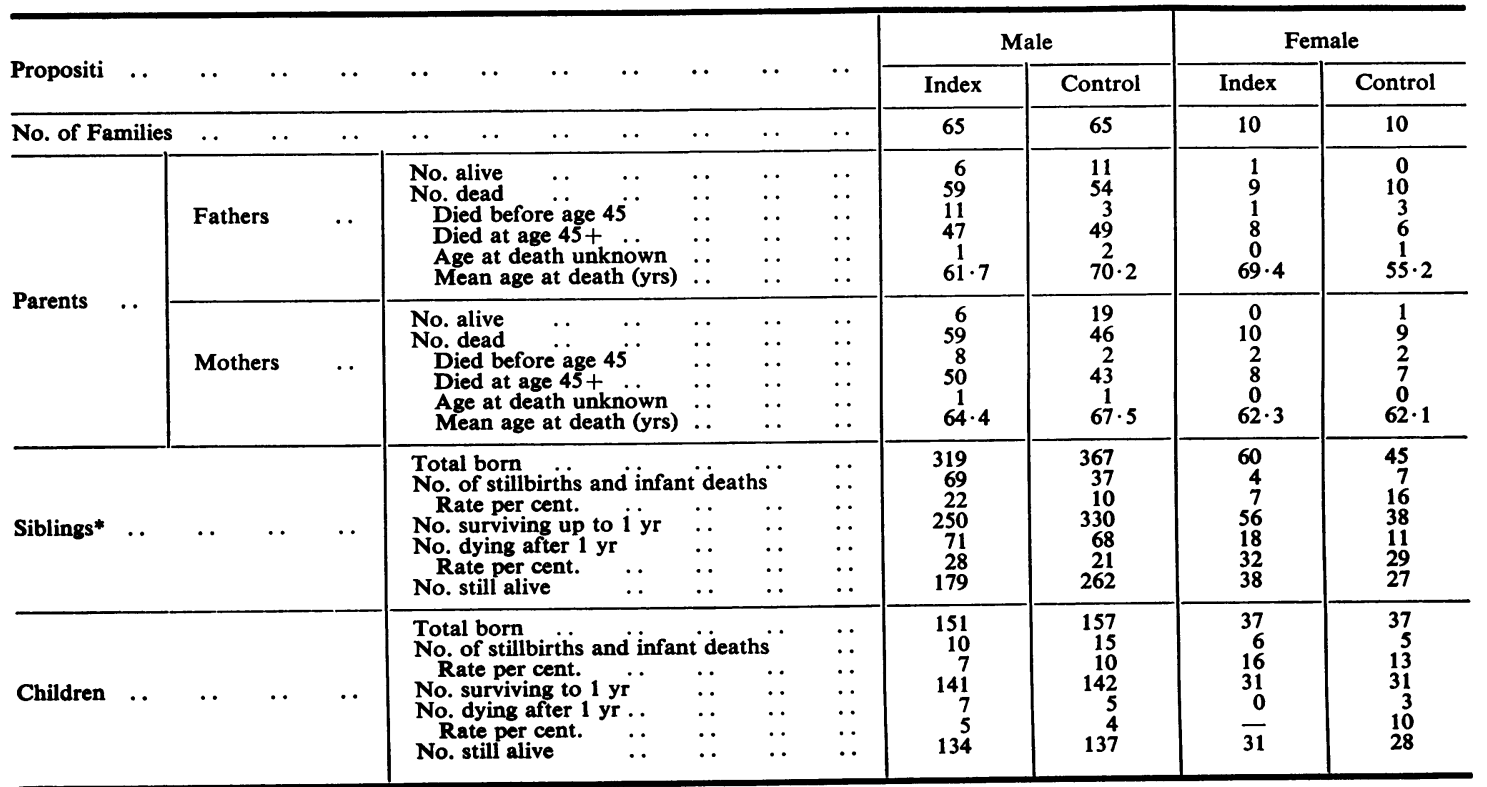

* Information unobtainable from one male index and one male control propositus. 
the reporting of family characteristics. There appeared to be a tendency for fathers-both index and control-to under-report minor illnesses, as compared with mothers (female propositae).

(b) Siblings of Propositi.-Table II shows that the index males came from somewhat smaller families, their mean number of siblings being 5.0 as compared with 5.7 for the controls (S.E. \pm 0.62 ; $P=0 \cdot 3 / 0 \cdot 2$ ). The difference was greatest in the $60+$ age group. More striking was the difference in subsequent mortality experience. At all ages the siblings of index males fared worse, but especially in childhood: in the first year of life they experienced a mortality double that of the controls. As a result of these differences in family size and mortality, the number of surviving siblings was almost 50 per cent. greater for controls than for the index group. The private patients tended to have smaller sibships and lower mortality. For female propositae numbers are small and no clear trends are seen.

(c) The Parental Generation.-There were similar trends in this generation also. The mean number of parental siblings (full brothers and sisters) was $9 \cdot 13$ for index males and $11 \cdot 16$ for controls (S.E. $\pm 0 \cdot 98$; $P=0 \cdot 05 / 0.02)$. The deficiency in the index group was approximately the same for uncles and aunts.

Data on mortality of parents of male propositi are also shown in Table II. In the index group nineteen parents (11 fathers and 8 mothers) died before the age of 45 , as compared with five ( 3 fathers and 2 mothers) in the control group; this is reflected in the differences between the two groups in mean parental age at death, amounting to 8.5 years for fathers and 3 years for mothers. Only two of the early ( $<45$ years) deaths of index parents were attributed to heart disease; five were attributed to non-tuberculous respiratory disease (as compared with none in the control group).

Possibly the difference in propositus sibship size might be related to early mortality of the parents. Where both parents survived to age 45 , the mean number of propositus siblings was nearly the same (5.2 for index males, $5 \cdot 6$ for controls), whereas when one or both parents had died before age 45 the mean numbers were $4 \cdot 0$ and $6 \cdot 6$ respectively. It was not possible to test the relationship of parental sibship size to early mortality among grandparents.

In summary then, there was excessive mortality in index families, not all due to heart disease, and most evident early in life. This excess was present in both the propositus generation and the parental generation, but its effect did not carry through to the children of propositi. In the parental generation at least it was associated with limitation of family size.
Of the 65 male index propositi, eight had coincidental diabetes, as compared with two of the corresponding control cases. This does not necessarily measure the true excess of diabetes in persons with ischaemic heart disease, since the presence of diabetes may possibly have influenced the chances of hospital admission among coronary subjects. But, among diabetes-negative (i.e. urine-negative) male propositi, the frequency of reported parental diabetes was 8 per cent. (8 cases) in the index group compared with 3 per cent. (4 cases) in the controls. The corresponding rates for affected siblings were 2 per cent. ( 5 cases) in the index group and 3 per cent. (10 cases) in the controls. Possibly there may be an excess of parental diabetes, but much larger numbers would be required to confirm this.

\section{Familial Aggregation of Ischaemic Heart Disease}

For present purposes a death is presumed to have been due to ischaemic heart disease if it was reported as either (a) coronary disease so diagnosed ("coronary thrombosis", "angina", etc.) or (b) "heart attack" not known to be due to other cause, or (c) sudden ( $<24$ hours) death, believed to have been cardiac. A non-fatal illness is presumed to have been ischaemic heart disease if it comes within categories (a) or (b). Other categories of heart disease were also recorded, but their incidence proved to be similar in the index and control groups.

Table III (overleaf) shows the frequency of presumed ischaemic heart disease among the firstdegree relatives of male propositi. There is an excess among index families; this is more or less confined to fatal illnesses, which were 2.7 times as frequent as in the control families. The excess arose mainly in the control families. The excess arose mainly in the parental generation, where it is very significant $(P=0.02 / 0.01)$. The numbers of affected siblings were small; and in any event they underestimate the true difference, since there were fewer index siblings at risk. A total of 24 index families (37 per cent.) included a fatal illness in a first-degree relative, as compared with nine (14 per cent.) of the control families $(P=0 \cdot 02 / 0 \cdot 01)$.

In the families of female propositae the findings were similar; there were twelve affected first-degree relatives ( 5 affected families) in the index group, as compared with five affected relatives ( 3 families) in the control group.

These results suggest the existence of familial aggregation. But the possibility cannot be excluded of some unidentified bias in the selection of controls. This danger can be avoided by a new approach 
TABLE III

PRESUMED ISCHAEMIC HEART DISEASE AMONG FIRST-DEGREE RELATIVES

\begin{tabular}{|c|c|c|c|c|c|c|c|c|c|c|c|c|c|c|c|}
\hline \multirow{3}{*}{$\begin{array}{l}\text { Propositi .. } \\
\text { Heart Disease }\end{array}$} & \multirow{3}{*}{$\begin{array}{l}\cdots \\
\cdots \\
\cdots\end{array}$} & \multirow{3}{*}{$\begin{array}{l}\cdots \\
\cdots \\
\cdots\end{array}$} & \multirow{3}{*}{$\begin{array}{l}\cdots \\
\cdots \\
\cdots\end{array}$} & \multicolumn{6}{|c|}{ Male } & \multicolumn{6}{|c|}{ Female } \\
\hline & & & & \multicolumn{3}{|c|}{ Index } & \multicolumn{3}{|c|}{ Control } & \multicolumn{3}{|c|}{ Index } & \multicolumn{3}{|c|}{ Control } \\
\hline & & & & Fatal & $\begin{array}{l}\text { Non- } \\
\text { fatal }\end{array}$ & Total & Fatal & $\begin{array}{l}\text { Non- } \\
\text { fatal }\end{array}$ & Total & Fatal & $\begin{array}{l}\text { Non- } \\
\text { fatal }\end{array}$ & Total & Fatal & $\begin{array}{l}\text { Non- } \\
\text { fatal }\end{array}$ & Total \\
\hline \multirow{3}{*}{$\begin{array}{c}\text { First-Degree } \\
\text { Relatives }\end{array}$} & & $\begin{array}{l}\text { Fathers } \\
\text { Mothers }\end{array}$ & $\cdots$ & $\left.\begin{array}{r}13 \\
9\end{array}\right\} 22 *$ & $\begin{array}{l}3 \\
1\end{array}$ & $\begin{array}{l}16 \\
10\end{array}$ & $\left.\begin{array}{l}6 \\
2\end{array}\right\} 8^{*}$ & $\begin{array}{l}6 \\
2\end{array}$ & $\begin{array}{r}12 \\
4\end{array}$ & $\begin{array}{l}2 \\
1\end{array}$ & $\begin{array}{l}1 \\
2\end{array}$ & $\begin{array}{l}3 \\
3\end{array}$ & $\begin{array}{l}2 \\
1\end{array}$ & $\begin{array}{l}0 \\
0\end{array}$ & $\begin{array}{l}2 \\
1\end{array}$ \\
\hline & & $\begin{array}{l}\text { Brothers } \\
\text { Sisters }\end{array}$ & $\cdots$ & $\begin{array}{l}4 \\
1\end{array}$ & $\begin{array}{l}7 \\
0\end{array}$ & 11 & $\begin{array}{l}2 \\
0\end{array}$ & $\begin{array}{l}2 \\
0\end{array}$ & $\begin{array}{l}4 \\
0\end{array}$ & $\begin{array}{l}3 \\
1\end{array}$ & $\begin{array}{l}0 \\
2\end{array}$ & $\begin{array}{l}3 \\
3\end{array}$ & $\begin{array}{l}1 \\
0\end{array}$ & $\begin{array}{l}1 \\
0\end{array}$ & $\begin{array}{l}2 \\
0\end{array}$ \\
\hline & & Total & . & 27 & 11 & 38 & 10 & 10 & 20 & 7 & 5 & 12 & 4 & 1 & 5 \\
\hline \multicolumn{3}{|c|}{ No. of Affected Families } & $\ldots$ & $24 t$ & 9 & 27 & $9 t$ & 10 & 16 & 4 & 4 & 5 & 2 & 1 & 3 \\
\hline
\end{tabular}

* †Difference significant at 0.02/0.01 level.

which dispenses with the need for any control group. In the absence of familial aggregation one would predict that the risk of ischaemic heart disease would be the same in all index families, and hence that variations between different families in the proportions of affected persons would be no more than could be expected on a chance basis. This hypothesis can readily be tested.

Among the 65 families of male index propositi there was reported a total of 44 affected persons. (The family unit here includes siblings, parents, and parental siblings; affected persons are cases of presumed ischaemic heart disease, fatal or non-fatal as defined earlier.) The frequencies of different sizes of family clusters of cases are shown in Table IV.

TABLE IV

DISTRIBUTION OF FAMILIES OF MALE PROPOSITI IN RELATION TO NUMBER OF MEMBERS WITH PRESUMED ISCHAEMIC HEART DISEASE

\begin{tabular}{c|c}
\hline $\begin{array}{c}\text { No. of Affected } \\
\text { Persons in Family }\end{array}$ & No. of Families \\
\hline 0 & 40 \\
1 & 12 \\
2 & 9 \\
3 & 3 \\
4 & 0 \\
5 & 1 \\
\hline Total & 65 \\
\hline
\end{tabular}

This distribution will be affected by the number of persons at risk in the various families; but by taking family size into account one may proceed to calculate whether the observed figures differ significantly from those to be expected on the basis of equality of risk in all families. The significance test for heterogeneity of such data is:

$$
\chi^{2}=\frac{\sum \frac{x_{i}^{2}}{n_{i}}-\frac{X^{2}}{N}}{\left(\frac{X}{N}\right)\left(1-\frac{X}{N}\right)}
$$

where $x_{i}=$ number of affected persons in a family

$n_{i}=$ number of persons at risk in the same family

$X=$ total number of affected persons

$N=$ total number of persons at risk.

The value obtained for $\chi^{2}$ is $102 \cdot 82$, which corresponds (on 64 degrees of freedom) to a value for $P$ of $<0.01$. In other words, within this defined population (the index males), there is a highly significant excess of bad-risk families.

The smallness of the numbers of affected individuals may raise doubts about the use of the $\chi^{2}$ test. But more exact calculations show that in fact $\chi^{2}$ in this particular instance is a very accurate test. Following the suggestion of Cochran (1954), the mean and variance of the $\chi^{2}$ statistic can be worked out in terms of the marginal totals, using formulae given by Haldane (1940). In the present example they are:

$$
\begin{aligned}
\operatorname{Mean}\left(\chi^{2}\right) & =64.08 \\
\text { Variance }\left(\chi^{2}\right) & =131.42
\end{aligned}
$$

as against the values 64 and 128 in the $\chi^{2}$ distribution on 64 degrees of freedom. The small numbers evidently result in only a very small increase in the variance of the $\chi^{2}$ statistic, and it is likely that the probability given by the $\chi^{2}$ tables (about 0.001 ) is reasonably correct. The normal approximation with this mean and variance gives a probability of about 0.004 . This is less than the probability for the $\chi^{2}$ table, in spite of the slightly greater variance, presumably because of the skewness of the $\chi^{2}$ distribution.

A similar result might be expected if in some families the members were older and had therefore been exposed to risk of the disease for a longer period. But the mean number of years at risk per family member was actually a little less in those families 
with affected members than in those without, and this alternative explanation cannot be accepted.

\section{Cause of Death, as stated at INTERVIEW, COM-} Pared With Death Certificate

The obtaining of relatives' death certificates was impeded by the wide scatter of the deaths in both time and place. The search was restricted to deaths of first-degree relatives which had occurred in the United States within the previous 20 years. A total of 54 index relatives' certificates was obtained, compared with 47 certificates of control relatives. The certified causes of death were compared with the causes stated by the propositi at interview. Those differences which relate to ischaemic heart disease are shown in Table $V$. There are no systematic differences between the index and control groups. This provides strong validation for the reliability of the interview data.

TABLE V

CHANGES IN PRESUMED CAUSE OF DEATH INTRODUCED WHEN DEATH CERTIFICATES OF PARENTS AND SIBLINGS WERE COMPARED WITH THE CAUSES STATED AT INTER VIEW

\begin{tabular}{|c|c|c|c|c|c|c|c|c|}
\hline \multirow{2}{*}{$\frac{\text { Propositi }}{\text { Changes }}$} & \multirow{2}{*}{$\frac{\cdots}{\ldots}$} & \multirow{2}{*}{$\begin{array}{l}\cdots \\
\cdots\end{array}$} & \multirow{2}{*}{$\frac{\cdots}{\ldots}$} & \multirow{2}{*}{$\frac{\cdots}{\ldots}$} & \multicolumn{2}{|c|}{ Index } & \multicolumn{2}{|c|}{ Control } \\
\hline & & & & & No. & $\begin{array}{l}\text { Per } \\
\text { cent. }\end{array}$ & No. & $\begin{array}{l}\text { Per } \\
\text { cent. }\end{array}$ \\
\hline \multicolumn{5}{|c|}{$\begin{array}{l}\text { Deaths in U.S.A. in Last } 20 \text { Years } \\
\text { Certificates not Traceable } \ldots\end{array}$} & $\begin{array}{l}80 \\
26\end{array}$ & $\begin{array}{r}100 \\
32\end{array}$ & $\begin{array}{l}69 \\
22\end{array}$ & $\begin{array}{r}100 \\
32\end{array}$ \\
\hline \multirow{2}{*}{\multicolumn{5}{|c|}{ 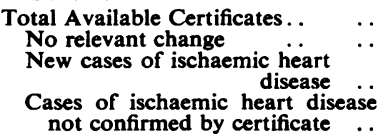 }} & $\begin{array}{l}54 \\
43\end{array}$ & $\begin{array}{l}68 \\
54\end{array}$ & $\begin{array}{l}47 \\
37\end{array}$ & $\begin{array}{l}68 \\
53\end{array}$ \\
\hline & & & & & $\begin{array}{l}9 \\
2\end{array}$ & $\begin{array}{r}11 \\
3\end{array}$ & $\begin{array}{l}8 \\
2\end{array}$ & $\begin{array}{r}12 \\
3\end{array}$ \\
\hline
\end{tabular}

\section{Discussion}

\section{VALIDITY OF THE RESULTS}

The general validity of this study depends on the absence of serious bias in the selection of controls and on comparability in the recording of information in the index and control groups.

The control group was chosen from patients with a wide variety of diagnoses: even if any one of these were associated with particular family characteristics, it would nevertheless have little influence on the results as a whole. Socio-economic bias may have occurred, for occupational matching was only approximate; and in fact the presence of a greater proportion of private patients in the index group suggests a somewhat higher socio-economic level. This should tend to produce a lower mortality in the family, particularly in childhood. Since the reverse was observed, it seems unlikely that this result at any rate was due to socio-economic selection bias.
It is nevertheless possible that for other, unidentified, reasons the control subjects were not representative of the population from which the index cases were derived, and that this may have caused some of the differences observed between the two groups. This limits the presentation of any hospital case-control study to a simple factual statement of the findings in that particular situation: generalizations are risky. But provided this limitation is borne in mind, the hospital study may be a valuable source of hypotheses for testing in a population study.

The investigation was designed to minimize the risk of biased reporting in one or other group. The standardized questionnaires were followed strictly, and the two observers each interviewed both index and control subjects. Checks on comparability were included in the form of questions on childhood illnesses, both of the propositi and of their children; these indicated close correspondence between the two groups. The possibility remains that persons with heart disease might thereby have a special awareness of heart disease in other members of their families. But there was no evidence of this when the causes of death stated at interview were compared with the death certificates (Table V).

\section{Family Size, MoRbidity, and MoRTality}

The largest difference observed between the two groups was in the number of surviving siblings, resulting from differences in both mortality and initial family sizes. The latter, however, seemed itself to be related to premature mortality of parents. The excess mortality in the two generations was not due primarily to an excess of heart disease. Indeed, in the proposital generation, it was greatest in infancy. Three interpretations may be considered:

(1) It may be that the greater mortality in index families resulted from lower socio-economic status. If this were so, however, one would have predicted larger rather than smaller families; for it is usual in a low-placed social group to find higher mortality but nevertheless more children (Whelpton and Kiser, 1943). Moreover, the greater number of private patients in the index group suggests a tendency to higher rather than lower social class. Thus, if this interpretation were correct, one would have to presume that the index propositi had ascended from a lower to a higher level on the social ladder. This would be consistent with the absence of any excess of stillbirths or infant deaths in the children of index propositi. (The absence of a disparity of family size in this generation can perhaps be explained by the fact that the propositi were nearly all aged over 45 , premature parental mortality thus being excluded.) 
(2) It may be that the stresses resulting from parental and sibling mortality themselves predispose to the occurrence of ischaemic heart disease.

(3) It may be that ischaemic heart disease tends to occur in individuals who come from a constitutionally weaker stock, more liable to succumb to a variety of diseases. Consistent with this would be the excess of previous hospital admissions in the index propositi.

The vital statistics of various countries have shown a consistent excess of arteriosclerotic heart disease mortality among widowers, especially in earlier life. This may be analogous to the excessive familial mortality shown in the present study. If so, the same possible interpretations would apply in both instances.

\section{Familial Aggregation}

The results have shown a significant excess of presumed ischaemic heart disease in the index parents. The reality of the excess is supported by the close agreement between the two groups in their reporting of other items of information, the evidence of the death certificate inquiry, and the demonstration that even within the index population familial cases occurred in clusters.

The occurrence of familial aggregation must not be taken to prove genetic predisposition. In other diseases, such as hypertension, the existence of familial resemblances has sometimes been too readily presumed to indicate a genetic basis (Hamilton, Pickering, Roberts, and Sowry, 1954). But family members resemble one another in many non-genetic respects. In the present context one could instance diet, physical activity, and environmentally-conditioned psychological traits as potentially causative factors which members of the same family tend to have in common. From the point of view of preventive medicine it is very important to consider such possibilities, for it may be possible to improve the life expectation of a member of a bad-risk coronary family by altering his habits or his environment.

\section{SUMMARY}

Familial characteristics of cases of ischaemic heart disease were studied by interviewing 75 survivors of cardiac infarction and 75 matched controls. The index cases reported an excess of unrelated previous hospital illnesses. Both they and their parents came from families which were smaller than those of the controls, but which nevertheless showed a higher mortality at all ages from a variety of causes. The siblings of index cases had experienced a stillbirth and infant mortality rate twice that of the controls.

Among the parents of index males there was a nearly 3-fold excess mortality from ischaemic heart disease. Study of a sample of death certificates suggested that this was not due to biased reporting. Even within the index group the familial cases showed significant clustering.

I am very grateful to Prof. V. A. McKusick, Prof. P. Armitage, Mrs D. Chilcoate, R.N., Mrs P. McPherson, R.N. (my fellow-interviewer), and Mrs B. M. Hunt for their assistance. The study was supported by Grant H-4180 from the National Heart Institute, U.S. Public Health Service.

\section{REFERENCES}

Ciocco, A. (1941). Hum. Biol., 13, 350.

Cochran, W.G. (1954) Biometrics, 10, 417.

Gertler, M. M., and White, P. D. (1954). "Coronary Heart Disease in Young Adults", pp. 22-35. Harvard University Press, Cambridge, Mass.

Haldane, J. B. S. (1940). Biometrika, 31, 346.

Hamilton, M., Pickering, G. W., Roberts, J. A. Fraser, and Sowry, G. S. C. (1954). Clin. Sci., 13, 273.

Manley, K. A., and McKusick, V. A. (1960). Bull. Johns Hopk. Hosp. 107, 213.

Russek, H. W., and Zohman, B. L. (1958). Amer. J. med. Sci., 235, 266.

Shanoff, H. M., Little, A., Murphy, E. A., and Rykert, H. E. (1961). Canad. med. Ass. J., 84, 519.

Thomas, C. B., and Cohen, B. H. (1955). Ann. intern. Med. 42, 90.

Whelpton, P. K., and Kiser, C. V. (1943). Milbank Mem. Fund Quart., 21, 221. 